\title{
Chapter 5 \\ Income Inequality and Socio-economic Segregation in the City of Johannesburg
}

\author{
Richard Ballard and Christian Hamann
}

\begin{abstract}
This chapter analyses income inequality and socio-economic segregation in South Africa's most populous city, Johannesburg. The end of apartheid's segregation in 1991 has been followed by both continuity and change of urban spatial patterns. There is a considerable literature on the transformation of inner-city areas from white to black, and of the steady diffusion of black middle-class residents into once 'white' suburbs. There has been less analysis on the nature and pace of socio-economic mixing. Four key findings from this chapter are as follows. First, dissimilarity indices show that bottom occupation categories and the unemployed are highly segregated from top occupation categories, but that the degree of segregation has decreased slightly between the censuses of 2001 and 2011. Second, the data quantifies the way in which Johannesburg's large population of unemployed people are more segregated from top occupations than any of the other employment categories, although unemployed people are less segregated from bottom occupations. Third, over the same period, residents employed in bottom occupations are less likely to be represented in affluent former white suburbs. This seemingly paradoxical finding is likely to have resulted from fewer affluent households accommodating their domestic workers on their properties. Fourth, although most post-apartheid public housing projects have not disrupted patterns of socio-economic segregation, some important exceptions do show the enormous capacity of public housing to transform the spatial structure of the city.
\end{abstract}

Keywords Johannesburg • Apartheid - Socio-economic segregation • Townships • Suburbs

R. Ballard $(\bowtie) \cdot$ C. Hamann

Gauteng City-Region Observatory (GCRO), a Partnership of the University of Johannesburg, the University of the Witwatersrand, Johannesburg, the Gauteng Provincial Government and Organised Local Government in Gauteng (SALGA), Johannesburg, South Africa e-mail: Richard.ballard@gcro.ac.za 


\subsection{Introduction}

The City of Johannesburg is the largest of eight metropolitan municipalities in South Africa with respect to population size and economy. It sits within a broader cityregion of 15 million people in the province of Gauteng, including the metropolitan municipalities of Tshwane to the north and Ekurhuleni to the east. The municipal jurisdiction of Johannesburg measures $1,648 \mathrm{~km}^{2}$ and includes urban, peri-urban and agricultural land uses. The population of Johannesburg grew by about $3 \%$ per annum between the 2001 and 2011 national census counts (from 3.2 to 4.4 million people). In line with national population composition, the majority of Johannesburg's population is black ${ }^{1}(78 \%)$. The second-largest population group, whites, constituted $12 \%$ of Johannesburg in 2011. Indians and Coloureds ${ }^{2}$ make up $6 \%$ and $4 \%$ of population, respectively. Education outcomes are improving; for example, the proportion of adults who have not been to school has fallen between 2001 and 2011 and the proportion of adults with tertiary education has increased. The average annual household income in Johannesburg (adjusted for inflation) increased by $2 \%$ per annum between 2001 and 2011 (Statistics South Africa (Stats SA) 2012a), but increases are highly uneven between population groups and across space.

Johannesburg was subject to intensive social and spatial engineering since its origins as a gold mining town in 1886. Given the emphasis that apartheid (19481994) placed on racial segregation, many analyses of spatial transformation in Johannesburg have focused on the endurance or breakdown of racial segregation (Beavon 2004; Christopher 1994; Crankshaw 2008). This chapter examines residential segregation between socio-economic groups rather than the more familiar focus on racial segregation. In doing so, we do not seek to claim any primacy of socio-economic segregation, but rather to consider the relationship between various kinds of social and spatial stratifications and the drivers of dominant residential patterns. In fact, it is not possible to separate social and spatial inequalities from each other or from racial segregation in the South African context. In the post-apartheid era, legal drivers of racial segregation have been abolished, but actual patterns of racial segregation are slow to change precisely because of various forms of socio-economic segregation and stratification. Furthermore, even where racial desegregation does occur, these processes do not necessarily disrupt socio-economic segregation.

\footnotetext{
${ }^{1}$ Statistics South Africa records data against four main population groups. Respondents self-identify as black, coloured, Indian/Asian or white.

${ }^{2}$ Whereas the term coloured in North America is a dated synonym for African Americans, in Southern Africa the meaning is quite different. It came to refer to mixed ancestry populations who were (in Apartheid's convoluted racial classifications) neither European (white) nor bantu (black), although they could have a heritage of both.
} 


\subsection{Drivers of Dominant Residential Patterns}

\subsubsection{Racial Segregation}

Johannesburg is a city of extremes, with densely populated working class townships ${ }^{3}$ (such as Diepsloot, Alexandra, Soweto and Orange Farm) juxtaposed against some of the richest neighbourhoods in Africa (Sandton and surrounding areas). Although apartheid formally ended in 1994, a century of white minority rule continues to affect many urban patterns. Apartheid's policies of racial segregation resulted in the division of residential areas between four different race groups: black, white, Indian and coloured. This shaped where new migrants to cities could settle and whether people could migrate to cities at all (many black people were forced to stay in rural 'homelands'). These policies also caused the relocation of large numbers of established urban residents. In the 1950s, for example, about 72,000 black people were moved from established areas of Johannesburg to the new settlement of Soweto on the south-western periphery of the city (Christopher 1994). Notwithstanding desegregation in many Johannesburg suburbs since the fall of apartheid, the overall population distribution and associated socio-economic patterns are tenacious (Fig. 5.1). By 2019, Soweto contained about 1.8 million people or a third of the city's population (Quantec 2018). Soweto, along with other townships, remains almost entirely black and poor relative to northern suburbs.

During the apartheid era, the white minority government tried to create a strong overlap between race, socio-economic status and space. Until 1980, better paying job categories were mostly reserved for whites, resulting in an income ceiling for black employees. Much more was spent on the education of white children than of other city dwellers (Seekings and Nastrass 2005). Until the 1980s, most black people could not own property in urban areas, including the homes they lived in. These and many other policies ensured that spaces intended for black residents were also workingclass spaces, with their residents having less capacity to earn and acquire assets than white residents of white-designated areas. As a result, there has been considerable inertia to these patterns beyond the repeal of discriminatory policies in the 1980s and early 1990s. Nowadays, black residents are no longer prohibited by law from living in former white suburbs. However, poorer residents of the city are financially excluded from more expensive areas. Since low-income earners are overwhelmingly black, and since expensive areas are often those that were historically designated for white use, some of apartheid's patterns continue.

Since the end of apartheid, some kinds of urban growth have produced entirely new black working-class settlements or have extended or intensified longer established townships. With racialized restrictions of urbanisation being lifted in 1986, a period of catch-up urbanisation saw many people migrate from rural areas and

\footnotetext{
${ }^{3}$ The common name for settlements established under apartheid for black residents, although Diepsloot and Orange Farm began much later than the others and are largely post-apartheid settlements.
} 

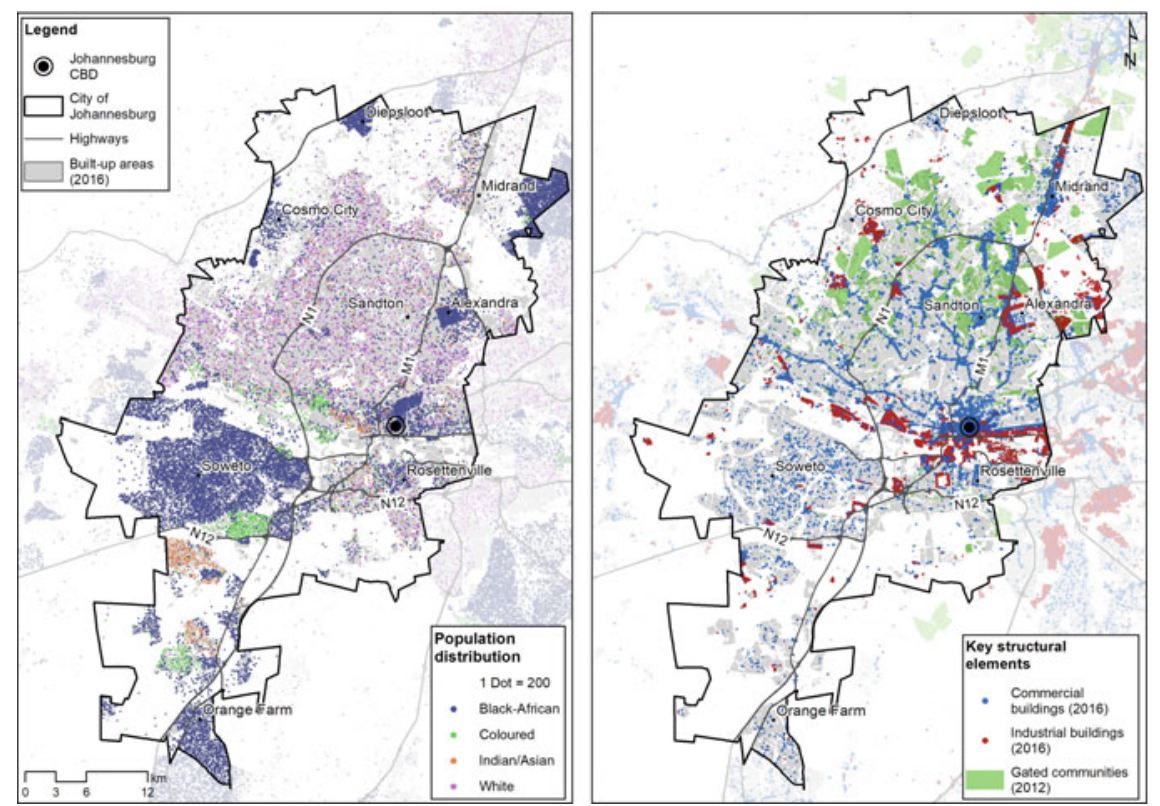

Fig. 5.1 The City of Johannesburg: Distribution of population groups (left) and the distributions of commercial and industrial buildings and gated communities (right). Data sources StatsSA (2011a, b), AfriGIS (2013), GeoTerraImage (2016)

smaller towns to larger cities (Turok 2014). Existing townships densified primarily because established residents living there built additional informal structures on their properties for rent. Some migrants settled in informal settlements, often alongside existing townships, or in entirely new settlements such as Orange Farm and Diepsloot. These relatively new settlements now contain hundreds of thousands of overwhelmingly black low-income earners. Since major economic opportunities are located in central areas (Fig. 5.1), large flows of commuters travel from these dormitory spaces to places of employment each day (Budlender and Royston 2016; Mohulatsi 2019).

It is important to qualify this impression of townships in two respects. First, apartheid-era townships do include some middle-class areas and some townships are better off than others. Therefore, although they do not exhibit racial diversity, townships have a socio-economic mix within and between them. Second, the apparent lack of ethnic diversity in 'black' areas is misleading in that these are extremely cosmopolitan spaces with a diversity of languages and nationalities (Hamann and Ballard 2017). 


\subsubsection{Housing}

Since the end of apartheid, the state has built new settlements as a way of addressing the housing demand. Households earning below R3,500 per month (\$241 in March 2019 prices) qualify for government housing. This often takes the form of a detached two-room 'low-cost house'. In the first two decades of democracy, the state delivered about 3.7 million of these houses nationally ${ }^{4}$ (The Presidency 2014). With an ongoing flow of new migrants to cities, and the division of households into smaller sizes, many people who qualify to be given government houses have yet to receive them. Others do not qualify because they earn above the threshold or are migrants from other countries. As a result, 18\% of dwellings in the province are informal dwellings, and a further $24 \%$ are unplanned-for backyard structures (Hamann 2018).

Although there have been instances of urban infill projects that break up apartheid patterns, both in terms of race and class, most government-provided housing has not done this (Charlton 2014). In 2013, the Johannesburg municipal government launched a programme called Corridors of Freedom which intends to densify and diversify residential neighbourhoods along Bus Rapid Transit routes, although this has yet to have a major impact (Ballard et al. 2017). Other housing projects involve upgrading settlements by clearing existing informal settlements and rehousing some of the residents in formal accommodation on the same site or elsewhere. However, the most common form of government-funded housing has been the development of new greenfield settlements with hundreds or thousands of units. Concerns that this approach will produce homogenous low-cost settlements, and therefore perpetuate segregation, resulted in a policy change in 2004 that promoted settlements with a higher mix of housing types, including fully subsidised, partially subsidised, and private (mortgage funded) homes (Department of Human Settlements 2004). A prominent example of this new generation of 'human settlements' is a 12,500unit settlement called Cosmo City on the north-western boundary of Johannesburg (Haferburg 2013).

While such settlements focus on social mixing, they do not achieve racial diversity as they are almost entirely black, given the nature of the housing backlog produced by apartheid. Such settlements do achieve some income mixing to a certain level, albeit with small-scale segregation between different kinds of housing within a settlement. However, the upper range of income in such settlements does not overlap substantially with the income ranges of more affluent suburbs. In 2014, the state announced plans to fund many more large-scale settlements of this kind, and given the shortage of land in established urban areas, they would likely occur on peripheral greenfield sites (Ballard and Rubin 2017). Private developers are also building low-density suburbs on cheap peripheral land for entry-level black home buyers (Butcher 2016).

Some apartheid spaces were comprehensively transformed, such as inner-city tower blocks and many low-rise central neighbourhoods. These areas were once reserved for white residents but became racially mixed in the 1980s and then became

\footnotetext{
${ }^{4}$ Housing delivery figures were not available at the city level.
} 
primarily black by the 1990s. The white residents that had once lived in innercity areas left because they were following work and lifestyle opportunities in the North, and also because of what they regarded as undesirable changes to inner-city neighbourhoods (Beavon 2004). Some buildings were abandoned by owners and occupied by economically marginal residents. As a result, conditions deteriorated, not least because electricity, water and sewerage were cut off when municipal accounts were no longer being paid (Murray 2008). Since the 2000s, developers began refitting some inner-city buildings for highly controlled working-class rental accommodation (Mosselson 2017). These spaces are diverse in terms of language, ethnicity and nationality if not race (almost all residents are black). In terms of class, inner-city areas are a mix of lower- and middle-class residents.

\subsubsection{Suburbs}

As noted above, suburbs with more affordable housing stock, like those close to the inner-city, experienced complete transitions from majority white to majority black populations. The activity of slumlords in some parts of such suburbs has suppressed their average income by allowing overcrowding of units and by underinvesting in general maintenance. Meanwhile, affluent northern suburbs once reserved for white residents have largely retained their expensive positions in the property hierarchy. Newer suburban housing stock for the middle- and upper-market tends to be 'gated', ranging from high-end golf estates to more modest 'townhouse' clustered development. This new housing stock is generally built on land adjacent to former white suburbs, for example, on smallholdings on the northern and western suburban fringe, but is also inserted into the suburban footprint when large suburban plots are redeveloped into denser clustered housing (Todes et al. 2017).

Many areas with expensive properties are dominated by white people, given their stronger buying capacity. However, since the white population only constitutes $12 \%$ of the city, it offers limited demand and there are many black, Indian and coloured residents with equally significant purchasing power. ${ }^{5}$ The removal of job reservation policies and the training of black nurses and teachers created a nascent black middle class in the 1980s (Crankshaw 1997). After the political transition in 1994, the upward mobility of some of the black population significantly reshaped social and spatial hierarchies (Seekings and Nastrass 2005; Crankshaw 2008). Those who did not stay in middle-class parts of townships moved to middle-class areas elsewhere in the city. As a result, suburbs once designated for white occupation are now some of the most racially integrated parts of the city. Many new cluster housing developments are also racially integrated (Chipkin 2012).

\footnotetext{
${ }^{5}$ According to the census the white population is ageing. There is also evidence of affluent white people migrating to Cape Town or even emigrating. Therefore as new professional jobs emerge they are taken up by individuals from other race groups who can then afford to live in more expensive suburbs.
} 
However, these processes of racial diversification within former white suburbs may be reinforcing broader patterns of socio-economic segregation (Kracker Selzer and Heller 2010). One analysis shows that the average household income in townships are not growing as fast as the provincial average, while many affluent areas are growing at a faster rate (Hamann and Cheruiyot 2017). The transfer of more affluent residents out of townships and into suburbs may account, in part, for this spatial divergence of average incomes. Former white suburbs also attract the overwhelming majority of private commercial and retail investment (Fig. 5.1).

Ironically, former white suburbs have lost a kind of race and class diversity that was integral to apartheid. Before democracy, many low-income black workers lived in 'white' suburbs as domestic workers on their employers' properties. Much of this accommodation has now been converted to rental accommodation (Falkof 2016), and many new cluster housing developments do not build 'servants' quarters' as would have once been standard in suburban housing. Domestic workers now are more likely to commute from townships. In 2019, the municipality of Johannesburg introduced an inclusionary housing policy to oblige developers of gated communities, cluster housing and apartments to incorporate more affordable options in their plans. This does not apply to the vast number of developments already built or that have already been given approval, so is yet to have a diversifying effect on the city.

While race and class are being, to some extent, untethered from one another in patterns of segregation in Johannesburg, it would be too simplistic to say that class is replacing race, since the historical processes of class formation were so comprehensively racialized. Even to the extent that racial integration is taking place through the upward mobility of some of the black population, the high levels of socio-economic inequality raise the important consideration of socio-economic segregation. In this chapter, we examine inequality and segregation of occupations following the broader methodologies of this volume in order to generate comparable findings.

\subsection{Inequality in Johannesburg}

\subsubsection{Data Sources}

In this chapter, occupation data is presented per sub-place in the City of Johannesburg for 2001 and 2011, the two most recent census dates. There are 804 sub-places in Johannesburg. Sub-places with zero population in either 2001 or 2011 were excluded from the analysis along with one other sub-place that is not a contiguous polygon and is geographically very large. The remaining sub-places vary somewhat in terms of geographic size but constitute loosely defined functional neighbourhoods. Subplaces had an average economically active population (i.e. all those aged between 15 and 65 years) of 2,158 people in 2011, ranging from one to 35,949 people. The major occupation categories, captured in the census by Statistics South Africa (Stats SA), are shown in Table 5.1. All employed, economically active respondents were 
Table 5.1 Changes in the occupation structure in Johannesburg, 2001-2011

\begin{tabular}{|c|c|c|c|c|c|}
\hline & $\begin{array}{l}\text { Major occupation } \\
\text { group }^{\mathrm{a}}\end{array}$ & 2001 & 2011 & Change & $\begin{array}{l}\% \text { change } \\
(\%)\end{array}$ \\
\hline \multirow[t]{2}{*}{ Top } & $\begin{array}{l}\text { Legislators; senior } \\
\text { officials and } \\
\text { managers }\end{array}$ & 85,291 & 179,621 & 94,330 & 110.6 \\
\hline & Professionals & 113,535 & 159,502 & 45,967 & 40.5 \\
\hline \multirow[t]{5}{*}{ Middle } & $\begin{array}{l}\text { Technicians and } \\
\text { associate } \\
\text { professionals }\end{array}$ & 104,439 & 145,056 & 40,617 & 38.9 \\
\hline & Clerks & 146,649 & 232,979 & 86,330 & 58.9 \\
\hline & $\begin{array}{l}\text { Service workers; } \\
\text { shop and market } \\
\text { sales workers }\end{array}$ & 137,764 & 336,264 & 198,500 & 144.1 \\
\hline & $\begin{array}{l}\text { Skilled agricultural } \\
\text { and fishery workers }\end{array}$ & 5,456 & 6,650 & 1,194 & 21.9 \\
\hline & $\begin{array}{l}\text { Craft and related } \\
\text { trades workers }\end{array}$ & 117,674 & 210,206 & 92,532 & 78.6 \\
\hline \multirow[t]{2}{*}{ Bottom } & $\begin{array}{l}\text { Plant and machine } \\
\text { operators and } \\
\text { assemblers }\end{array}$ & 71,636 & 58,563 & $-13,073$ & -18.2 \\
\hline & $\begin{array}{l}\text { Elementary } \\
\text { occupations }\end{array}$ & 218,441 & 392,740 & 174299 & 79.8 \\
\hline \multicolumn{2}{|c|}{ Undetermined $^{\mathrm{b}}$} & 77,482 & 9,560 & $-67,922$ & -87.7 \\
\hline \multicolumn{2}{|l|}{ Total } & $1,080,368$ & $1,733,152$ & 652,784 & 60.4 \\
\hline
\end{tabular}

Data source Quantec $(2014,2016)$ (Quantec packages and distributes various economic and demographic datasets in South Africa, including boundary reallocated census data from Stats SA.) ${ }^{a}$ Definitions are provided by Stats SA (2012b)

'The 'Undetermined' category was excluded from the totals for the rest of the analysis

asked two questions to determine their occupation — one about the kind of work that the respondent does and the other about the main task or duty in their daily work (Stats SA 2011a). These questions were used to code occupations according to the South African Standard Classification of Occupation (SASCO).

\subsubsection{Changes in Occupational Structure}

In Johannesburg, the workforce increased by 60\% between 2001 and 2011 (Table 5.1). Similar changes are evident in other metropolitan municipalities in South Africa. Increases are the largest in Johannesburg, followed by the other two metropolitan municipalities in Gauteng where the workforce increase by $55 \%$ and $51 \%$ in Tshwane and Ekurhuleni, respectively. In Johannesburg, the biggest change is seen in the number of people employed as service workers or shop and market sales 


\begin{tabular}{|c|c|c|c|c|c|c|c|c|c|c|c|c|c|c|c|}
\hline \multicolumn{6}{|c|}{$\%$} & \multicolumn{10}{|c|}{$\%$} \\
\hline & 20 & 40 & 60 & 80 & 100 & 0 & 20 & & 40 & 50 & 60 & & 80 & 90 & 100 \\
\hline 2001 & 20 & 51 & & 29 & 2001 & 9 & & 10 & 15 & 14 & $\begin{array}{ll}1 & 12\end{array}$ & 7 & & 22 & \\
\hline 2011 & 20 & 54 & & 26 & 2011 & 10 & 9 & 8 & 14 & 20 & $\begin{array}{lll}0 & 12\end{array}$ & 3 & & 23 & \\
\hline
\end{tabular}

Fig. 5.2 Changes in the share of major occupations in Johannesburg, 2001-2011. Data source Quantec $(2014,2016)$

workers (144\% increase). As Beall et al. (2002) note, service sector jobs bifurcate into well paid and poorly paid. Sellers are likely to be employed in the fast-growing retail sector but the job opportunities in this sector remain unevenly distributed in the urban space. Most formal sector retail facilities are in the suburbs north of the Johannesburg Central Business District (CBD) along with suburban office nodes and there are proportionally fewer retail and office facilities in townships and the south of the city (Fig. 5.1; Beavon 2004).

The number of legislators, senior officials and managers also increased significantly (by 110\%), as a result of the development of various strong business nodes (like Sandton) and the swelling ranks of the public sector. Changes in the occupational structure further reflect the decreasing importance of manufacturing, as also observed in previous studies (Rogerson and Rogerson 2015; Seekings and Nastrass 2005). Plant and machine operators are the only occupational group that declined (by $18 \%$ ). However, the number of people employed in elementary occupations has increased. Taken together, the share of top occupations has remained the same between 2001 and 2011, while the share of middle occupations increased by $3 \%$ and the share of bottom occupations decreased by 3\% (Fig. 5.2). Figure 5.2 also shows the breakdown of each major occupation and reveals that the share of service workers increased by $6 \%$ while the share of machine operators declined by $4 \%$.

\subsubsection{Income Inequality}

South Africa's Gini coefficient during apartheid was estimated to have been between 0.58 and 0.68 , making it one of the most unequal countries in the world. According to Seekings and Nastrass (2005: 188) "inequality in South Africa was higher at the end of the apartheid period than in, even, most other middle-income countries". Apartheid's racialized income distribution continues to influence mean income. Nationally, the average income of white household heads was 4.8 times the average for black household heads in 2014-15 (Stats SA 2017). However, the upward mobility of some of the black population, particularly since the 1980s, means that inequality was no longer just driven by differences in income between races, it was increasingly driven by 
intra-racial income inequality. In 2008, Crankshaw predicted that "the major spatial and class division in the post-Fordist spatial order [of Johannesburg] may become characterised by a division between a racially desegregated middle class, on the one hand, and a largely black working class on the other" (Crankshaw 2008: 1695, also see Beall et al. 2002).

Crucially, unemployment has increased since the mid-1970s, and in the province of Gauteng, the unemployment rate was 32\% during 2011 (Stats SA 2011b). This is the result of economic restructuring that has followed the exhaustion of gold mines and the restriction of manufacturing by international competition. We agree with Seekings and Nastrass (2005) that inequality is no longer just the result of differences in wages, but also a result of the differences between the employed and unemployed. It is important to note here that unemployment varies significantly between population groups. Black people are overrepresented in the ranks of the unemployed, while white people are underrepresented.

Post-apartheid income inequality has fluctuated. In Johannesburg, a sharp increase in income inequality was evident between 1995 and 2001 (from 0.54 to 0.58), followed by minor increases until about 2005 (to 0.6), and decreasing thereafter to 0.58 in 2014 (Quantec 2015). The trends in Johannesburg are similar to the national trends, but income inequality in Johannesburg is slightly lower than national levels. Johannesburg also has lower levels of income inequality than the two adjacent metropolitan municipalities. This is influenced, amongst other factors, by the strong economy of Johannesburg relative to other cities in South Africa and by the largely urban population. By way of international comparison, income inequality in Nairobi (Kenya) is 0.59, Sao Paulo (Brazil) is 0.55, Mexico City (Mexico) is 0.49, and Moscow (Russia) is 0.45 (UN Habitat 2016).

\subsection{Socio-economic Segregation in Johannesburg}

Trends and patterns in statistics over time help to set the scene for our understanding of socio-economic inequality, but the spatial dimensions and patterns of these statistics are valuable in understanding socio-economic segregation. In this section, we provide various calculations that illustrate socio-economic segregation, mostly between the top and bottom occupation groups (managers and professionals versus machine operators and elementary occupations). Analysing these patterns over time highlights how the socio-economic structure of Johannesburg has shifted and what prospects there are for future socio-economic integration.

\subsubsection{Dissimilarity Index}

We calculated Dissimilarity Index (DI) values (as explained in the introduction of this book) between all the major occupations as well as the top, middle and bottom 
Table 5.2 Indices of dissimilarity (multiplied by 100) between major occupations in Johannesburg, 2001-2011

\begin{tabular}{|c|c|c|c|c|c|c|c|c|c|c|c|c|c|c|}
\hline & \multicolumn{13}{|c|}{ DI 2011} \\
\hline & & MN & PRO & TEC & CLE & SER & AGR & CRA & $\mathrm{MC}$ & ELE & UNE & TOP & MID & BOT \\
\hline \multirow{13}{*}{$\begin{array}{l}\text { 오 } \\
\text { ㅁ } \\
\overline{0}\end{array}$} & MN & & 13 & 26 & 27 & 43 & 37 & 50 & 54 & 44 & 63 & & & \\
\hline & PRO & 12 & & 29 & 31 & 47 & 41 & 55 & 59 & 49 & 67 & & & \\
\hline & TEC & 22 & 26 & & 12 & 27 & 33 & 35 & 39 & 32 & 46 & & & \\
\hline & CLE & 37 & 41 & 18 & & 22 & 31 & 30 & 33 & 28 & 41 & & & \\
\hline & SER & 48 & 51 & 32 & 24 & & 38 & 18 & 21 & 17 & 28 & & & \\
\hline & AGR & 54 & 56 & 49 & 48 & 44 & & 41 & 45 & 39 & 51 & & & \\
\hline & CRA & 58 & 61 & 42 & 31 & 26 & 39 & & 15 & 14 & 20 & & & \\
\hline & $M C$ & 64 & 67 & 47 & 37 & 31 & 46 & 15 & & 21 & 18 & & & \\
\hline & ELE & 42 & 44 & 31 & 30 & 22 & 34 & 21 & 28 & & 26 & & & \\
\hline & UNE & 70 & 72 & 53 & 42 & 36 & 50 & 20 & 13 & 33 & & & & \\
\hline & TOP & & & & & & & & & & & & 39 & 47 \\
\hline & MID & & & & & & & & & & & 42 & & 18 \\
\hline & ВОт & & & & & & & & & & & 48 & 20 & \\
\hline
\end{tabular}

$M N$ Managers; PRO Professionals; TEC Technicians; CLE Clerks; SER Service and sales workers; $A G R$ Skilled agricultural workers; $C R A$ Crafts and related trade workers; $M C$ Plant and machine operators; ELE Elementary occupations; UNE Unemployed

occupation groups (Table 5.2). As an important contextual consideration, we also included unemployment as an additional DI calculation, but to remain within the scope of the book we did not further investigate unemployment in the rest of the analysis. According to the DI values, top-bottom segregation and middle-bottom segregation decreased slightly but top-middle segregation decreased more substantially (see summary figures in the lower right corner of Table 5.2). Segregation between most occupations decreased, on average by $5 \%$. The increase in service workers is clearly associated to lower segregation levels with all other occupations (an average $6 \%$ decrease). On the other hand, segregation between managers and elementary occupations increased slightly (by $2 \%$ ) and segregation between professional and elementary occupations increased by $5 \%$.

These indices of dissimilarity between top, middle and bottom occupations are necessarily for employed people. As Table 5.2 shows, unemployed people are much more likely to be segregated from top occupations than any of the other occupations, although even here the degree of segregation between unemployed and top occupations had decreased slightly by 2011 .

\subsubsection{Location Quotient}

In this section, we analyse the spatial concentration of the top and bottom occupations by using the location quotient (LQ) measure of segregation (as explained in the introduction of this book). Figure 5.3 shows that very few sub-places represent situations where the mix of occupation groups in the sub-place is similar to the mix for the city as a whole (light grey sub-places). Turquoise-shaded areas in the upper maps of 
Top occupations

$L Q \min 2001=0$

LQ $\max 2001=2.89$

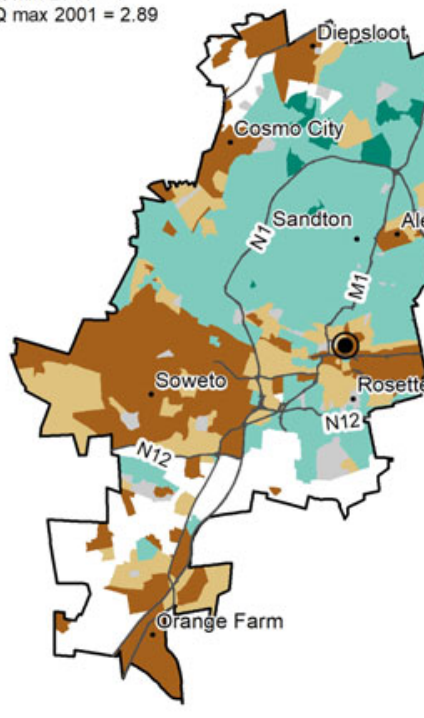

$L Q \max 2011=3.81$

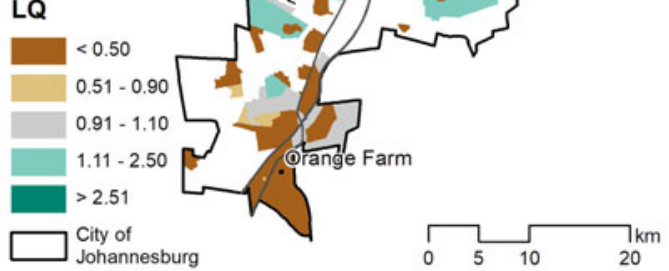

\section{Bottom occupations}

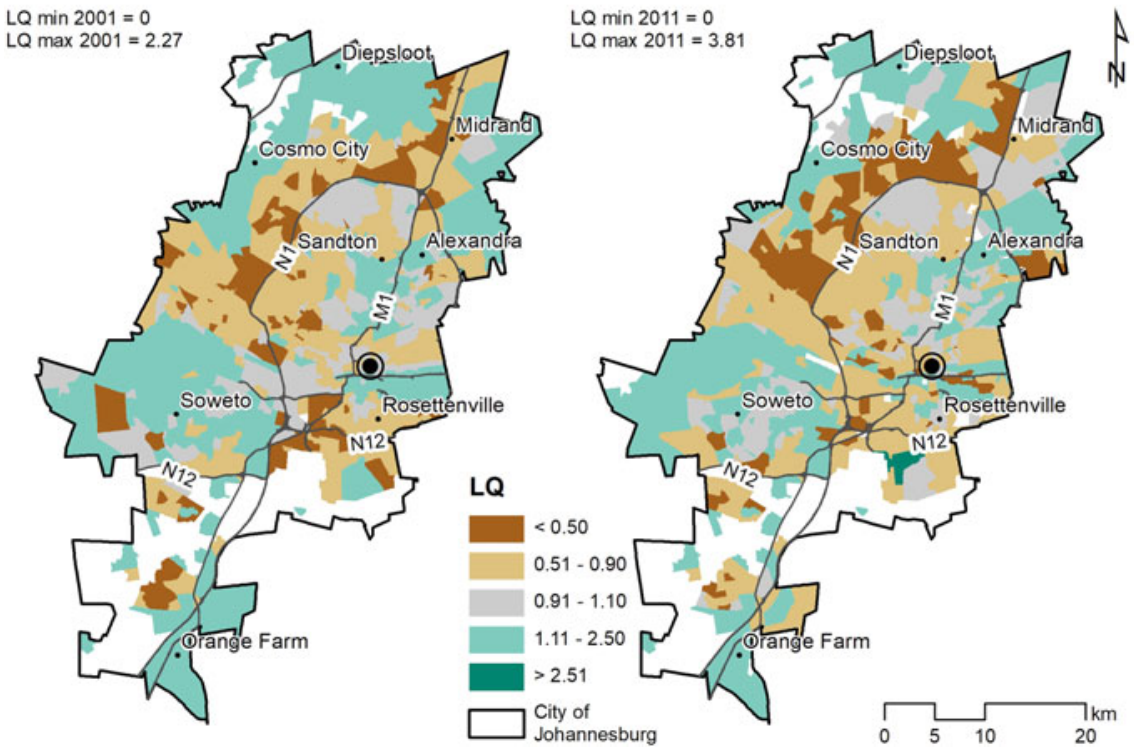

Fig. 5.3 Location quotient of top and bottom occupations in Johannesburg, 2001-2011. Data sources Quantec $(2014,2016)$ 
Fig. 5.3 are those in which top occupations are overrepresented while areas shaded brown in the upper figures are those in which top occupations are underrepresented. The highly clustered overrepresentation of top occupations (LQ higher than 1.10) in 2001 and 2011 is apparent in much of northern Johannesburg, and some isolated parts of southern Johannesburg. By contrast, the Johannesburg CBD and townships, such as Diepsloot, Soweto and Orange Farm show an underrepresentation of top occupations in 2001 and 2011. By 2011, the underrepresentation of top occupations decreased slightly in some areas, particularly in Soweto, Cosmo City and north of Orange Farm. Their significant underrepresentation directly east of Sandton is due to the presence of the working-class township of Alexandra. From 1912, black people were able to own land in the 'freehold' settlement of Alexandra, and as the city grew north, Alexandra became an unusual case of a centrally-located township.

In the lower two maps, turquoise-shaded areas are those in which bottom occupations are overrepresented, while brown is where they are underrepresented. Those employed in bottom occupations are less spatially clustered than those employed in top occupations, but they are overrepresented on the fringes of the city and in townships like Soweto and Diepsloot (Fig. 5.3). The residential population of the Johannesburg CBD shows a slight underrepresentation of bottom occupations in 2001, increasing in 2011. Given that the CBD population is also highly underrepresented by top occupations, it is likely that the CBD provides affordable homes and easy access to middle occupations such as technicians, clerks, service workers and trades workers. In 2001, bottom occupations were slightly overrepresented (LQ between 1.11 and 2.5) in some suburbs surrounding Sandton. These concentrations around Sandton would include domestic workers that lived on the properties of middle- and upper-class employers. As anticipated above, we see evidence for the reduction of this employment category in these suburbs by 2011 as such workers now commute from townships and other settlements. The increasing underrepresentation of bottom occupations is even more striking in the arc of suburbs west of the N1 highway. These suburbs contain many new cluster housing developments for middle- and upper-class home buyers but provide limited accommodation for domestic workers.

\subsubsection{Classification of Neighbourhoods by Socio-economic Composition}

The socio-economic status (SES) of neighbourhoods can be determined by the proportion of occupations that are considered top, middle or bottom occupations. For the neighbourhood classification in Fig. 5.4, the classification used by Marcińczak et al. (2015) was altered slightly and two categories were added afterwards to allow for the unambiguous classification of all sub-places in Johannesburg. The neighbourhood types that were slightly adapted include High SES (top $>=50$; middle $<=35$; bottom $<=35$ ), Middle SES (top $<=35$; middle $>=50$; bottom $<=35$ ) and Low SES (top $<=35$; middle $<=35$; bottom $>=50$ ). Thereafter, the remaining uncategorised 


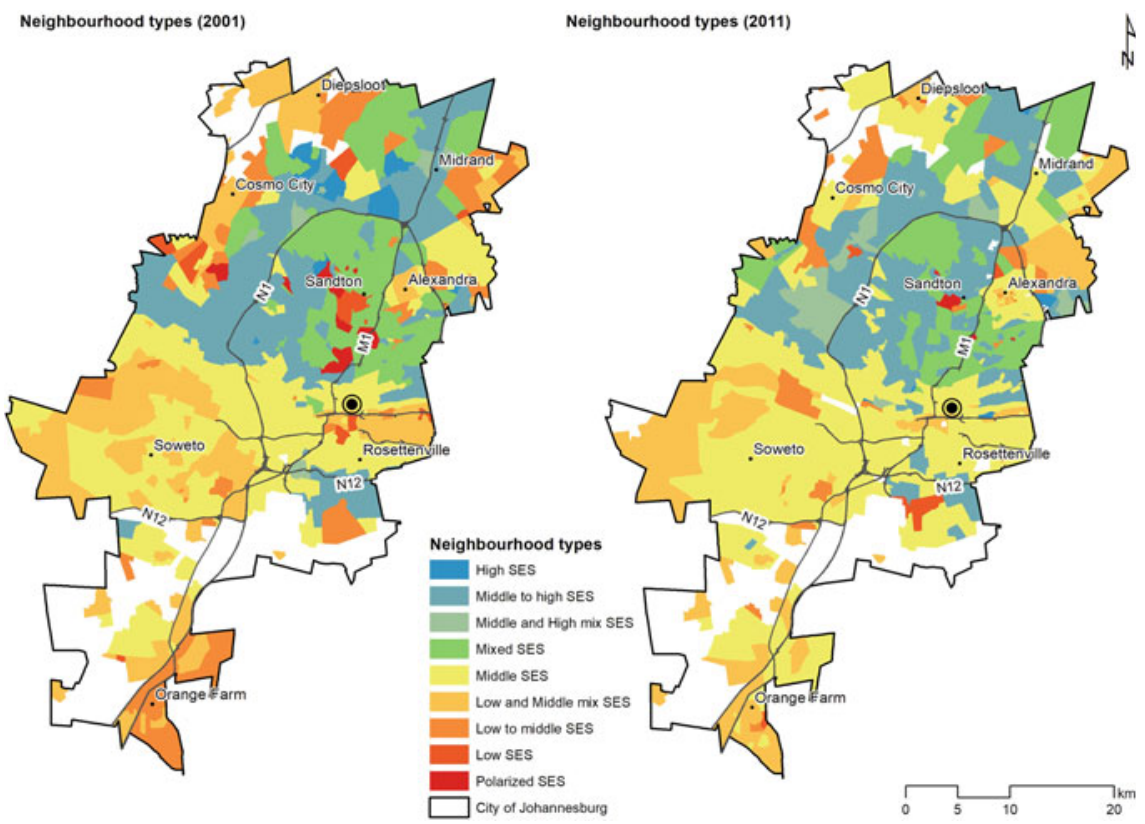

Fig. 5.4 Neighbourhood types in Johannesburg, 2001-2011. Data sources Quantec (2014, 2016)

sub-places were grouped into Middle and High mix SES (top $>=25$; middle $>=25$; bottom $<=25$ ) or Low and Middle mix SES (top $<=25$; middle $>=25$; bottom $>=$ 25).

A clear spatial distinction exists between predominantly higher SES neighbourhoods in northern Johannesburg (with exceptions on the suburban fringes) and predominantly lower SES neighbourhoods in southern Johannesburg (with the exception of a cluster of neighbourhoods south of Rosettenville which are higher SES). This distinct separation of neighbourhoods echoes the observation by Crankshaw (2008: 1701) that "all the neighbourhoods with more than two thirds of the population being middle class are in the northern suburbs, none are in the South". Suburbs between the N1 and M1 highways (which also contain the most expensive properties in the city) are predominantly high, middle to high or mixed SES, with an increase in high SES suburbs north of Sandton in 2011. Suburbs with mixed SES around Sandton and Midrand could be attributed to two possible characteristics. First, there may be quite different occupation ranks within one household resulting from gender, age and other stratifications in the labour market. Second, it could reflect the development of relatively affordable cluster housing that has made these areas accessible to residents employed in a greater mix of occupations. Low and polarised SES suburbs around Sandton in 2001 are likely associated with the overrepresentation of top and bottom occupations discussed alongside Fig. 5.3, above, and largely disappears by 2011. The lower SES of Alexandra, directly east of high SES areas around Sandton, is a striking feature of Johannesburg's geography. 
The development of large luxury gated estates, private commercial investment and cluster housing around Midrand has also shifted neighbourhoods from mixed SES to high SES. Meanwhile, some public housing projects have also made a measurable difference to socio-economic desegregation. The area labelled Cosmo City was low to middle SES and low SES in 2001. With the construction of a major state-led housing project there from 2004, the occupation mix had elevated to middle SES by 2011. Moreover, the category middle SES contains a mix of top, middle and bottom occupations and this suggests that Cosmo City has achieved its goal of creating a more mixed-income urban environment than had been achieved in previous public housing projects. Figure 5.4 also indicates that the Johannesburg CBD has an increasingly middle SES. In the south of Johannesburg, the classification of suburbs in townships are a testament to the socio-economic mix of these residential spaces. Soweto is almost entirely characterised by middle SES, a change that is partly due to the removal and formalisation of informal settlements in the township (Huchzermeyer et al. 2014).

\subsubsection{Location of Top Socio-economic Status Groups in 2001 and 2011}

In 2001 and 2011, the top $20 \%$ of managers and professionals lived in $2 \%$ of subplaces in Johannesburg (Fig. 5.5). The location of the quintile 1 sub-places has not changed substantially but remains mostly located north and west of Sandton. No more than two of these sub-places were located south of the Johannesburg CBD in either 2001 or 2011. It is important to bear in mind that the quintile 1 sub-places have relatively low population densities and vary in geographic size, especially in comparison to dense sub-places in townships such as Soweto and Diepsloot. Quintile 1 suburbs were established throughout the twentieth century with freestanding houses on large plots. From the 1990s, many of these neighbourhoods were retrofitted with access control gates and new suburban developments were built with fences and gates from the outset while also attracting substantial private commercial and retail investment (Fig. 5.1). In this representation of the concentration of top occupations, it is again evident that the proportion of top occupations increased in sub-places close to the northern edge of Johannesburg (e.g. around Midrand). There has also been a slight increase in the proportion of top occupations in parts of Soweto and in Cosmo City. 

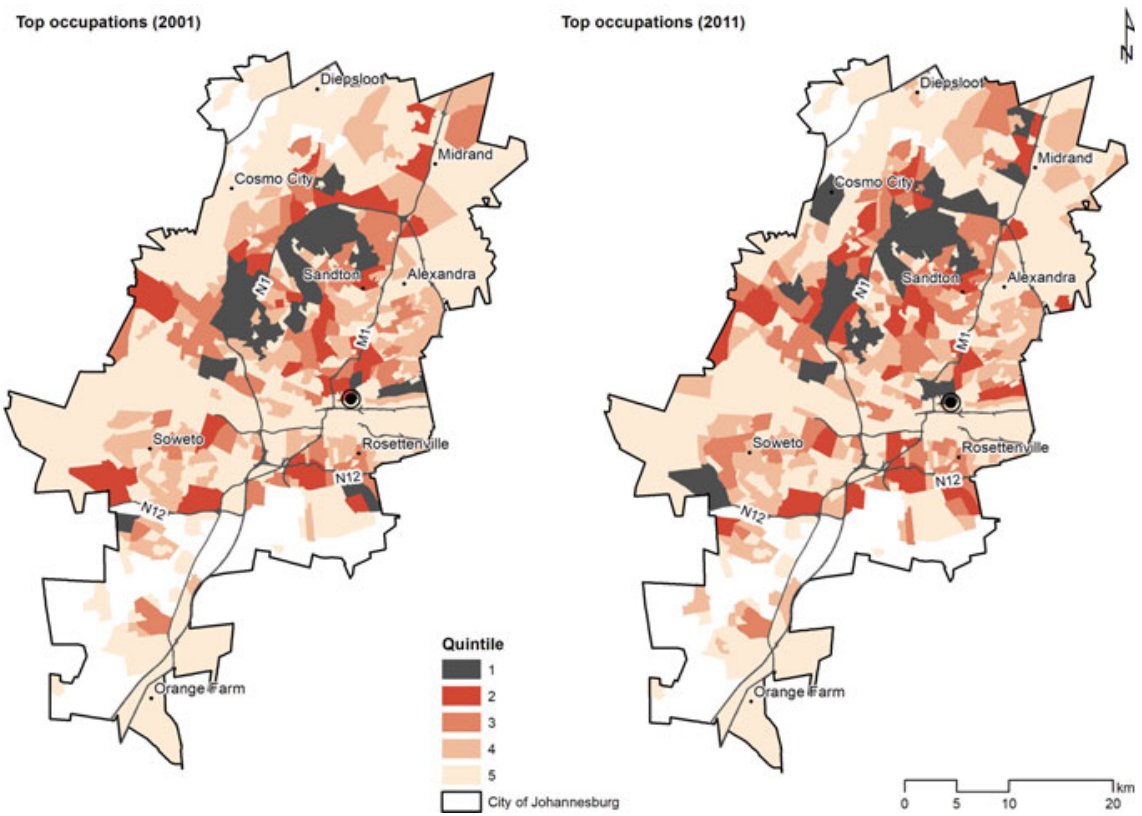

Fig. 5.5 The concentration of the top socio-economic group in Johannesburg, 2001-2011. Data sources Quantec $(2014,2016)$

\subsection{Conclusion}

Segregation by race was apartheid's defining ambition, and one that was actively pursued until the political transition of the early 1990s. In attempting to stratify society and space racially, the programmes of white minority governments also influenced socio-economic stratification. They produced settlements with cheaper property for the black working class and more expensive suburbs for the white working class, middle class and elites. Since the end of apartheid, income inequality amongst black people has grown dramatically. Given the strong purchasing power of some black, Indian and coloured people, suburbs once set aside for white people are now racially diverse.

Yet the calculations presented in this chapter show the way in which different occupations continue to be segregated. The transition from a Fordist secondary economy to a post-Fordist service economy has served some better than others (Beall et al. 2002; Crankshaw 2008) and unemployment also remains high. Managerial jobs have been particularly robust, consolidating and expanding the position of those at the highearning end of the income spectrum. Machine operators have diminished, while in their place low paid unskilled, industrial and retail sector categories have grown. The effect of this employment profile is that the Gini coefficient in Johannesburg remains amongst the highest in the world. Thus, the repeal of racial restrictions has no bearing 
on the inability of the low-earning black majority to afford housing in more expensive suburbs once reserved for white occupation. The dissimilarity index between top and bottom occupation groups decreased slightly between the 2001 and 2011 censuses but increased between other occupation groups. The concentrations of top and bottom occupations illustrate the polarised structure of Johannesburg described by Crankshaw (2008) as being divided into northern suburbs (mostly middle class) and the southern suburbs or townships (mostly working class).

Residential development and job markets have both reproduced the spatial nature of socio-economic inequality and facilitated key changes. Although state-provided housing might have acted somewhat independently of the market to break up these patterns, it has largely failed to do so. Essentially, long-term and deeply entrenched inequalities have not changed substantially notwithstanding the scrapping of apartheid segregation. The 2016 Johannesburg Spatial Development Framework recognises these enduring patterns of socio-economic segregation and the city has subsequently proposed more proactive responses to the situation, including densification along transit corridors and inclusionary housing. Our analysis does suggest that state housing developments such as Cosmo City has enabled a greater mix of occupations than what was previously possible. Whether these proactive measures can offset market-led production of residential space is an important issue for the coming decades.

\section{References}

AfriGIS (2013) Gated communities in Gauteng. AfriGIS. https://www.afrigis.co.za/

Ballard R, Rubin M (2017) A "Marshall Plan" for human settlements: how megaprojects became South Africa's housing policy. Transform Crit Perspect South Afr 95:1-31. https://doi.org/10. 1353/trn.2017.0020

Ballard R, Dittgen R, Harrison P, Todes A (2017) Megaprojects and urban visions: Johannesburg's Corridors of Freedom and Modderfontein. Transform Crit Perspect South Afr 95:111-139. https:// doi.org/10.1353/trn.2017.0024

Beall J, Crankshaw O, Parnell S (2002) Uniting a divided city: governance and social exclusion in Johannesburg. Earthscan, London

Beavon K (2004) Johannesburg: the making and shaping of the city. University of South Africa Press, Pretoria

Budlender J, Royston L (2016) Edged out: spatial mismatch and spatial justice in South Africa's main urban areas. Socio-economic Right Institute of South Africa. http://www.seri-sa.org/ima ges/SERI_Edged_out_report_Final_high_res.pdf. Accessed 10 Feb 2017

Butcher S (2016) Infrastructures of property and debt: making affordable housing, race and place in Johannesburg. PhD, University of Minnesota

Charlton S (2014) Public housing in Johannesburg. In: Harrison P, Gotz G, Todes A, Wray C (eds) Changing space, changing city: Johannesburg after apartheid. University of the Witwartersrand Press, Johannesburg, pp 176-193

Chipkin I (2012) Middle classing in Roodepoort capitalism and social change in South Africa. Public Affairs Research Institute, Johannesburg

Christopher AJ (1994) The atlas of apartheid. Routledge, London

Crankshaw O (1997) Race, class, and the changing division of labour under apartheid. Routledge, London 
Crankshaw O (2008) Race, space and the post-fordist spatial order of Johannesburg. Urban Stud 45(8):1692-1711. https://doi.org/10.1177/0042098008091497

Department of Human Settlements (2004) "Breaking new ground" a comprehensive plan for the development of sustainable human settlements. http://www.dhs.gov.za/sites/default/files/docume nts/BREAKING\%20NEW\%20GROUND\%202004_web.pdf. Accessed 28 Aug 2019

Falkof N (2016) Out the back: race and reinvention in Johannesburg's garden cottages. Int J Cult Stud 19:627-642. https://doi.org/10.1177/1367877915581856

GeoTerraImage (2016) Building-based land use layer. GeoTerraImage. http://www.geoterraimage. com/products-landuse.php

Haferburg C (2013) Townships of To-Morrow? Cosmo City and inclusive visions for post-apartheid urban futures. Habitat Int 39:261-268. https://doi.org/10.1016/j.habitatint.2012.10.014

Hamann C (2018) Change in residential buildings. Gauteng City-Region Observatory, Johannesburg, Map of the Month, 31 October. https://www.gcro.ac.za/outputs/map-of-the-month/detail/ change-in-residential-buildings/. Accessed 26 Sept 2019

Hamann C, Ballard R (2017) Dimensions of diversity in Gauteng. Gauteng City-Region Observatory, Johannesburg, Map of the Month, 29 September. http://www.gcro.ac.za/outputs/map-ofthe-month/detail/dimensions-of-diversity-in-gauteng/. Accessed 13 Mar 2019

Hamann C, Cheruiyot K (2017) Differentiating household income growth in Gauteng 2001-2011. Gauteng City-Region Observatory, Johannebsurg, Map of the Month, 31 October. http://www.gcro.ac.za/outputs/map-of-the-month/detail/differentiating-household-inc ome-growth-in-gauteng-2001-2011/. Accessed 13 Mar 2019

Huchzermeyer M, Karam A, Maina M (2014) Informal settlements. In: Harrison P, Götz G, Todes A, Wray C (eds) Changing space, changing city: Johannesburg after apartheid. Wits University Press, Johannesburg, pp 154-175

Kracker Selzer A, Heller P (2010) The spatial dynamics of middle-class formation in postapartheid South Africa: enclavization and fragmentation in Johannesburg. In: Go J (ed) Political power and social theory, vol 21. Emerald Group Publishing Limited, Bingley, pp 171-208

Marcińczak S, Tammaru T, Novák J, Gentile M, Kovács Z, Temelová J, Valatka V, Kährik A, Szabó B (2015) Patterns of socio-economic segregation in the capital cities of fast-track reforming postsocialist countries. Ann Assoc Am Geogr 105(1):183-202. https://doi.org/10.1080/00045608. 2014.968977

Mohulatsi B (2019) Population concentrations: night vs day. http://www.gcro.ac.za/outputs/mapof-the-month/detail/population-concentrations-night-vs-day/. Accessed 13 Mar 2019

Mosselson A (2017) 'Joburg has its own momentum': towards a vernacular theorisation of urban change. Urban Stud 54:1280-1296. https://doi.org/10.1177/0042098016634609

Murray M (2008) Taming the disorderly city: the spatial landscape of Johannesburg after apartheid. Cornell University Press, Icatha

Quantec (2014) 2001 sub-place community profiles. https://www.easydata.co.za/. Accessed $20 \mathrm{Feb}$ 2019

Quantec (2015) Gini coefficient at 2011 municipal level (ward-based region for metros) 1995-2014. https://www.easydata.co.za/. Accessed 13 Dec 2018

Quantec (2016) 2011 sub-place community profiles. https://www.easydata.co.za/. Accessed $20 \mathrm{Feb}$ 2019

Quantec (2018) Population group at 2011 local municipal/ward-based metro region level 19932017. https://www.easydata.co.za/. Accessed 14 Sep 2018

Rogerson CM, Rogerson JM (2015) Johannesburg 2030: the economic contours of a "Linking global city". Am Behav Sci 59(3):347-368. https://doi.org/10.1177\%2F0002764214550303

Seekings J, Nastrass N (2005) Class, race, and inequality in South Africa. Yale University Press, London

Statistics South Africa (2011a) Census 2011 metadata. http://www.statssa.gov.za/?page_id=3955. Accessed 11 Dec 2018

Statistics South Africa (2011b) Quarterly labour force survey. Quarter 3, 2011. https://www.statssa. gov.za/publications/P0211/P02113rdQuarter2011.pdf. Accessed 6 Mar 2019 
Statistics South Africa (2012a) Census 2011 Municipal report: Gauteng. http://www.statssa.gov. za/?page_id=3955. Accessed 6 Mar 2019

Statistics South Africa (2012b) South African Standard Classification of Occupation (SASCO). http://www.statssa.gov.za/classifications/codelists/SASCO_2012.pdf. Accessed 26 Feb 2019

Statistics South Africa (2017) Living conditions of households in South Africa: An analysis of household expenditure and income data using the LCS 2014/2015. Pretoria. http://www.statssa. gov.za/publications/P0310/P03102014.pdf. Accessed 18 Mar 2019

The Presidency (2014) Twenty year review, South Africa, 1994-2014. Republic of South Africa, Pretoria. https://www.dpme.gov.za/news/Documents/20\%20Year\%20Review.pdf. Accessed 22 Aug 2019

Todes A, Harrison P, Weakley D (eds) (2017) Resilient densification: four studies from Johannesburg. South African Research Chair in Spatial Analysis and City Planning, Johannesburg

Turok I (2014) South Africa's tortured urbanisation and the complications of reconstruction. In: McGranahan G, Martine G (eds) Urban growth in emerging economies: lessons from the BRICS. Routledge, Abingdon, pp 143-190

UN Habitat (2016) World cities report 2016: urbanization and development, emerging futures. United Nations Human Settlements Programme, Nairobi. http://wcr.unhabitat.org/wp-content/ uploads/2017/02/WCR-2016-Full-Report.pdf

Open Access This chapter is licensed under the terms of the Creative Commons Attribution 4.0 International License (http://creativecommons.org/licenses/by/4.0/), which permits use, sharing, adaptation, distribution and reproduction in any medium or format, as long as you give appropriate credit to the original author(s) and the source, provide a link to the Creative Commons license and indicate if changes were made.

The images or other third party material in this chapter are included in the chapter's Creative Commons license, unless indicated otherwise in a credit line to the material. If material is not included in the chapter's Creative Commons license and your intended use is not permitted by statutory regulation or exceeds the permitted use, you will need to obtain permission directly from the copyright holder.

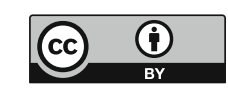

